May 2 Sir William Bragg lectured on "Refrigeration" and on May 30 Lord Rutherford on "Helium and other Rare Gases". These two lectures were attended by many members of both Houses of Parliament, and others engaged in public affairs, and at the first of them the Prime Minister presided.

THE success which has attended these lectures has encouraged the belief that the continuance of the series is desirable. The intention is to afford those concerned in the public affairs and industries of the country an opportunity of keeping themselves informed of scientific developments and of the progress of scientific research, particularly in its social and economic bearing and its applications to industry. The managers of the Royal Institution have agreed to co-operate with the council of the British Science Guild in the arrangement of a further programme of four lectures. The subjects have been chosen from four branches of science-electricity, acoustics, metallurgy and biology -in which there have been specially interesting developments in recent years. In each case, the lecturer will describe some notable scientific principle or discovery and trace its consequences down to the point at which the practical and industrial applications which have flowed from it have become matters of national or even wider significance. The following lectures, for the first of which the invitations have now been issued, will be on Wednesdays at 9 p.m.: Mr. C. C. Paterson, on "The Liberation of the Electron: Its Industrial Consequences" (Nov. 21) ; Dr. G. W. C. Kaye, on "Sound and Noise" (Dec. 12) ; Prof. C. H. Desch, on "The Microscope and the Metal Industries" (Feb. 6) ; Sir Frederick Keeble, on "The Fertility of the Earth" (March 6).

\section{Developments in British Air Transport}

THE recent air race to Melbourne has focused attention upon the possibilities of air transport to that particular part of the British Empire, and Sir Philip Sassoon, Under-Secretary for Air, has stated that the Air Ministry, the Post Office and Imperial Airways have been working for many months on plans for further development of commercial air transport. He emphasised the fact that this action on the part of the authorities was not in any way attendant upon the result of this race, but was the natural culmination of continuous investigation and methodical application of the improvements in the technique of aeronautics to air transport problems. $\mathrm{He}$ stated that he hoped to be able to announce within the next month or two, in conjunction with the Dominions and Colonies, plans that will result in the flying time between London and the Empire capitals being progressively and drastically reduced, and also that steps towards the desiderata of reasonably constant loads in both directions will be taken by further developing air mail traffic.

AIr mail traffic probably offers the simplest form of experiment in the system of carrying by relays of fast machines, the obvious solution to the problem, as the question of personal fatigue of the passengers does not affect the case. Having established optimum conditions for this class of traffic, it will be possible to investigate the variations in it necessary when dealing with the human element. This will possibly prove more expensive in the first instance, as it will call for the use of special mail-carrying aircraft, which will not be hampered, either in their design or their proportion of time in the air to time on the ground, by considerations of passengers' comfort. With this class of machine it should be possible rapidly to approach times of the order established during the recent race. The present system of designing for and operating with a mixed traffic of mails, goods and passengers, with the additional necessity of running the air line as a paying com. mercial proposition so far as is possible, always presents the vague and incalculable problem of the personal element of the passengers' requirements. This can only be solved by the relative slow method of short steps in introducing improvements with elimination of the unsatisfactory ones by trial and error.

\section{England-Melbourne Air Race}

THE official times now announced for the Centenary Air Race from England to Melbourne are : Scott and Black (D.H. Comet), 64 hr. 48 min. 49 sec.; Par. mentier and Moll (Douglas D.C. 2), $76 \mathrm{hr} .38 \mathrm{~min}$. 12 sec.; C. J. Melrose (D.H. Moth), $79 \mathrm{hr} .17 \mathrm{~min}$. 50 sec.; Stodart and Stodart (Airspeed Courier), 79 hr. 32 min. 30 sec. ; Macgregor and Walker (Miles Hawk), 82 hr. 43 min. 34 sec.; Hewett and Kay (D.H. Dragon), 85 hr. $42 \mathrm{~min} .28 \mathrm{sec}$; Hansen and Jensen (Desoutter), $87 \mathrm{hr} .45 \mathrm{~min} .21 \mathrm{sec}$ Mr. C. W. A. Scott and Mr. T. Campbell Black have therefore been given the prize of $£ 10,000$ as winners of the speed race; they have also been awarded the British Silver Medal of the Royal Aeronautical Society for their flight.

\section{Inland Water Survey}

Writing in reference to our leading article on "Inland Water Survey" in the issue of Nature of October 27, Mr. Alan Chorlton, M.P., says that while generally supporting the project for the institution of a survey at an early date, he considers there are other factors which should be taken into account. To arrive at the total of the water supplies of Great Britain without proper relation to where they are likely to be called for would be, he fears, to create another break in the development of water supply in the country. He alludes to an air survey for the positioning of aerodromes and notes that town and country planning call for something to be done to bring the Ordnance Survey up to date. It seems to him that consideration should be given to the general interrelation of all these matters in order to ensure that they will ultimately be properly co-ordinated. "A water survey should, at least, be undertaken with relation to the areas the water is required for : that is, a combination of survey with the recommended allocation".

As regards water supply generally, Mr. Chorlton finds that a statutory central water authority is not 